\title{
A REVIEW OF AQUACULTURE RESEARCH IN CROATIA PUBLISHED IN THE CROATIAN JOURNAL OF FISHERIES SINCE 1938
}

\author{
Mate Zani $\bar{c}^{1}$, Tea Tomljanović ${ }^{2 *}$, Daniel Matulić \\ ${ }^{1}$ Omega 3, Milene Rakvin Mišlov 1, Kali, Croatia \\ 2 University of Zagreb, Faculty of Agriculture, Department for Fisheries, Beekeeping, Game Management and \\ Special Zoology, Svetošimunska 25, Zagreb, Croatia
}

*Corresponding Author, Email: ttomljanovic@agr.hr

\section{ARTICLE INFO \\ Received: 1 February 2017 \\ Received in revised form: 23 February \\ 2017 \\ Accepted: 1 March 2017 \\ Available online: 1 March 2017}

\section{Keywords:}

Statistics

Disease

Management

Economics

Nutrition

Product quality

\begin{abstract}
151 articles published in the Croatian Journal of Fisheries from 1938 until 2016, covering aquaculture research in Croatia, have been included in this study. Published articles have been classified into seven groups based on their main topics. Topics include: aquaculture statistics in Croatia; disease and health care; farming technology; management, economics and environmental protection; fish nutrition and product quality; improving aquaculture; and species biology and ecology. The study concisely informs about aquaculture research in Croatia since 1938. Due to large contribution to the research, development and quality management of Croatian aquaculture, further promotion and development of Croatian Journal of Fisheries is required.
\end{abstract}

How to Cite

Zanić, M, Tomljanović, T., Matulić, D. (2017): A review of aquaculture research in Croatia published in the Croatian Journal of Fisheries since 1938. Croatian Journal of Fisheries, 75, 76-84. DOI: 10.1515/cjf-2017-0011.

\section{INTRODUCTION}

The Croatian Journal of Fisheries (CROAT J FISH) is a peer-reviewed scientific and technical journal which was first published in 1938 under the name Ribarstvo ("eng. Fisheries"). In the first issues of the Journal, the articles focused on the profession and problem solving in freshwater fisheries, at a later point extending to open waters, legislation, sport fishing and aquaculture. While previously published research (Antonović and Treer, 2015) gives a contribution to the knowledge of studies in ichthyology of
Croatian open freshwaters published in CROAT J FISH from 1938 - 2014, the aim of this article is to review all collected data of aquaculture development in Croatia from 1938 to 2016 published in the CROAT J FISH. Also, by reviewing all the available editions of the CROAT J FISH it is possible to make conclusions about aquaculture research and production trends in Croatia as well as determine the basic guidelines for aquaculture future development. Research on aquaculture in Croatia published from 1938 to 2016 is divided into several groups according to the area they cover. Most of the articles refer to the inland water culture and 
only a small part to mariculture. The reason for this is that mariculture started developing only in the 1970 and Morsko Ribarstvo (eng. "Marine Fisheries") journal, which contained articles on marine research, was published in parallel with the publication of the Croatian Journal of Fisheries. In this paper, 151 scientific and professional articles on Croatia's aquaculture have been processed and divided into seven groups (Table 1) according to their topic.

Table 1. Aquaculture research in Croatia published in the Croatian Journal of Fisheries from 1938 to 2016 by topic

\begin{tabular}{lc}
\hline \hline Article Topic & $\begin{array}{c}\text { Number of } \\
\text { published articles }\end{array}$ \\
\hline Aquaculture statistics in Croatia & 50 \\
Disease and health care & 26 \\
Farming technology & 25 \\
Management, economics and & 16 \\
environmental protection & \\
Fish nutrition and product quality & 15 \\
Improving aquaculture & 11 \\
Species biology and ecology & 7 \\
\hline \hline
\end{tabular}

\section{AQUACULTURE STATISTICS IN CROATIA}

With the first publication of the Croatian Journal of Fisheries in 1938, Josip Plančić (1938) published a paper titled "Inland fisheries of Savska Banovina" in which he mentioned approximate freshwater fish production of about 20,000 quintals, (about 2,000 tons) in this specific Croatian region. Furthermore, production statistics have been published only since 1955 for the previous year (Basioli, 1955). Basioli published annual statistics which specified the amount of wild-caught and farmed fish, farmed species, consumption of feed and fertilizer, as well as problems in farming, under the title Freshwater fisheries of the People's Republic of Croatia in the year 1954. Then, the same author published two more works $(1960,1961)$ under the same title and later under the title Inland freshwater fisheries of the Socialist Republic of Croatia (1962-1979). His work is continued by Turk (1980-1999). Turk published fisheries statistics under the same title until 1990. From 1990 to 1999, he published papers under the name Croatian freshwater fisheries. Jahutka and Homen (2001) continued to record the production and published a paper titled Freshwater fisheries of the Republic of Croatia in the year 2000 with proposed measures for solving production problems. Also, Jahutka and Homen (2003) published a work titled Croatian freshwater fishery in 2001 and 2002. Jahutka et al. (2004; 2005; 2006; 2007) published works which, along with previous data on freshwater production, include mariculture production. The last article related to production statistics was published by
Mišura et al. (2008) for 2007. Milinković (1988) published statistics on the production and consumption of trout in Yugoslavia for 1987.

\section{DISEASE AND HEALTH CARE}

The first article on fish diseases was published by Fijan (1947) who described ascites, i.e. belly disease in carp Cyprinus carpio (belly disease is caused by the bacterium Pseudomonas punctata). Fijan described the disease and indicated huge losses of $5-80 \%$ in ponds in the early spring. Taler (1948a) also studied this disease and provided an overview of the history of occurrence of the disease and measures for its control. Vegh (1948) reported the damage caused by this disease on a fish farm at Pisarovina. Tomašec (1953) wrote about parasites in fish intestines and pointed to the importance of animal hygiene and stock density in farms. Wunder (1954) described foulbrood of carp gills in ponds in the area of the former Yugoslavia. Fijan et al. (1962) described carp louse which appeared on fish farms and its control using lindane lotion, and Fijan (1963) cited the occurrence of dactylogirosis for the first time in 1962 and claimed that the disease had not yet been systematically studied. Tomašec and Kunst (1965) cited the diseases that occurred during hibernation of carp and described the conditions necessary for wintering of carp. Kunst (1965) argued that ectoparasites in ponds made a big problem and proposed the application of lotions for the treatment of ectoparasitic diseases in carp ponds. The treatment of infectious dropsy of carp was attempted by adding antibiotics in feed. The first research on the activity of antibiotics in the feed was conducted in Croatia in 1964 on an experimental fish farm in Draganić (Livojević and Habeković, 1966). Fijan (1970) described infectious pancreatic necrosis for the first time in Croatia in salmonid species. He also determined measures to be implemented in the case of disease. Taler (1948b) described gas bubble disease which was found in trout on a farm on the River Gacka. Križanac and Teskeredžić (1980) addressed the emergence of bacterial nephritis in rainbow trout Oncorhynchus mykiss (Walbaum 1792) after mass mortalities due to inadequate feed and suggested ways of treatment. He described the path of disease diffusion to Croatia and its treatments. Kapetanović and Teskeredžić (2004) described Aeromonas bacteremia in salmonids caused by the bacterium Aeromonas hydrophila. Fijan (1971) proposed measures to combat the disease on farms. Kezić and Fijan (1974) suggested that the swim bladder inflammation had occurred in Croatia for several years but the aetiology of this disease had not yet been fully understood. In 1972, it was found that infectious dropsy in carp was not caused by the bacterium Aeromonas punctata back then, and spring viraemia and erythrodermatitis of carp were isolated from it. Then he proposed to stop using the name and the concept of infectious dropsy (Fijan, 1978a). 
Fijan (1978b) argued that herbivorous fish did not suffer from infectious diseases that were common for carp, for example goddess, gill necrosis, branchiomycosis. Also, he stated that saprolegniasis, secondary infections after an injury and during the hatching of eggs, is not dangerous for herbivores. (Petrinec et al., 1983) noted that in the winter period 1981/1982 and 1982/1983 there was high mortality of silver carp Hypophthalmichthys molitrix in two ponds in Croatia. It was found that the fish was infected by Pseudomonas fluorescens. Studies have shown that, after harvesting, transportation and inoculation of silver carp at low temperatures, death may be caused by the bacterium P. fluorescens. However, the occurrence and development of infection was primarily attributed to stress. Hacmanjak (1985) described telohanelosis caused by parasites of the genus Thelohanellus. It often appears in carp ponds and the most important and safest method to prevent the occurrence and spread of telohanelosis is the implementation of general preventive health measures. Haematopoietic necrosis, which can cause mortality in fingerlings of up to $90 \%$, is first mentioned in Croatia by Fijan (1989) who stated that it was caused by an RNA virus of the rhabdovirus group. Tomec et al. (1995) explored the impact of water quality on the occurrence of ectoparasites in cyprinid species. Topić Popović and Teskeredžić (1999) cited shellfish diseases and toxins regulated by law. Čadež (2005) argued that till then there had been no record of high mortality on shell farms in Croatia and he described diseases regulated by law, namely iridovirosis, bonamiosis, microcytosis, haplosporidiosis and perkinsosis. Kurtović and Teskeredžić (2001) described some zoonotic diseases and their effects. Parasites, bacteria and viruses can be directly or indirectly transmitted from fish, shellfish and crustaceans to humans. The most frequent are parasitic diseases because humans are hosts to many parasites during their life cycle. Čičin-Karlov and Teskeredžić (2005) conducted a study on infestations of marine fish reared in cages.

\section{FARMING TECHNOLOGY}

Fijan (1948) stated that spawning of perch Sander lucioperca began in Croatia as early as 1946 and he described the process of artificial seeding in open waters. Fijan (1952) also described the process and technology for the culture of carp fingerlings. Čehović (1952) stated in his study conducted in 1950 that by using the solution of crushed carp hypophysis, artificial spawning of loach Cobitis taenia was successfully implemented out of spawning season. He also alleged that artificial spawning of pike Esox lucius was successfully implemented the following year. Regarding artificial spawning, Čehović described the technique of extracting carp hypophysis, which in that time had advantage over techniques of other authors. The first entry of herbivorous species on the Croatian territory was recorded in 1966 on a fish farm at Končanica (Fijan and Vojta, 1969). Other common species that have been grown in polyculture with carp are catfish Silurus glanis perch, tench Tinca tinca and pike. Fijan and Vojta (1969) conducted artificial spawning of grass carp Ctenopharyngodon idella and silver carp (Hypophthalmichthys molitrix) on a fish farm atKončanica and, three years later, Marko and Stoisavljević (1972) presented the spawning results of grass carp Ctenopharyngodon idella on a fish farm at Grudnjak. Livojević (1970) stated that it was possible, with proper nutrition, fertilization and other breeding techniques, to achieve yields in ponds of 2,000 $\mathrm{kg} / \mathrm{ha}$. Bauer (1974) considered the introduction of gravity systems in outdoor pools in natural conditions of spawning and rearing. Kuhinek (1979) stated that the fish farm at Končanica planned to start the production of eel Anguilla anguilla. Cage farming was a new way of intensifying the cultivation of freshwater fish. Habeković (1978) stated that a test breeding of trout in cages on Lake Peruća was conducted and it was concluded that there was economic justification for cage breeding of rainbow trout. Also, Habeković (1982) stated that even the third breeding cycle set in 1977 proved economic justification for test cage breeding of rainbow trout. Debeljak and Turk (1981) conducted a study and they concluded that favourable planting density in ponds affected an increase in production. Habeković et al. (1981) conducted experimental breeding of whitefish Coregonus peled in Lake Peruća in 1978 and demonstrated that whitefish was suitable for cultivation. Labar and Toth (1983) reported that Danilo Štampalija Fishing Net Factory in Biograd na moru produced the first floating platform for hanging net cages in 1979. It was designed so that it was possible to walk to each cage and some floating structures could be tied in a sequence. Herbivorous fish do not naturally spawn in temperate zones, but it is possible to conduct hybridization under artificial spawning methods. Turk and Habeković (1981) described the process of hybridization of bighead carp Hypophthalmichthys nobilis (Richardson 1845) males and silver carp females in the experimental ponds in Draganić. Also, Habeković and Turk (1981) listed some data on the selection of carp in the Socialist Republic of Croatia. Matulić et al. (2009) stated that, by the development of molecular genetics, genetic markers which had direct or indirect effects on the production value or which supported the selection in aquaculture had been increasingly used. Experimental cage breeding of catfish Silurus glanis (Ržaničanin et al., 1984a) and carp Cyprinus carpio (Ržaničanin et al., 1984b) was done for the first time in Croatia in 1983 on Lake Vrana near Biograd na moru. Ržaničanin et al. concluded that the cage breeding of carp in Lake Vrana was not cost-effective in comparison to catfish farming, so they continued to research cage farming of catfish in 1984 (Ržaničanin et al., 1986). The first attempt at breeding marine fish was carried out in the Bay of Cres in 1974 - common pandora Pagellus erythrinus (Linnaeus 1758) was reared in cages. It turned 
out that fish grew well but it was not possible to harvest enough fingerlings for commercial cultivation (Teskeredžić, 1985). Peharda (2000) described experimental setup of polyethylene bags which were used as collectors for shellfish while Šarić et al. (2010) discussed about importance of biofilters in recirculating aquaculture. The main obstacle to increasing carp production in ponds was high mortality in early stages of life, therefore Jelkić et al. (2012) conducted a research on technology of rearing of carp larvae in a closed recirculating system to minimise the loss. Župan et al. (2013) described the relocating of Noah's Ark Arca noae from natural conditions to different conditions of experimental cultivation.

\section{MANAGEMENT, ECONOMICS AND ENVI- RONMENTAL PROTECTION}

Fijan (1966) described largemouth bass Micropterus salmoides as an excellent additional species in cultivation, whereas Sabioncello et al. (1970) described the advantages of breeding catfish also as a supplementary fish in carp ponds. Popović and Habeković (1978) described the economic importance of tench in polyculture with carp. Advantages of polyculture of herbivorous fish and carp were described by Turk (1978) in his research on the experimental fish farm in Draganic where carp was stocked with grass carp, silver carp, catfish and largemouth bass. He concluded that polyculture was convenient because it reduced feed consumption and helped pond self-fertilisation. Turk (1984) published an article on successful farming of herbivorous fish for the previous twenty years; also Turk et al. (1987) published the results of breeding and market trends for herbivorous fish from 1977 to 1986. Bauer (1970) discussed economic benefits of mechanization on fish farms. Bavčević et al. (2001) covered management in aquaculture and they proposed coastal zone planning, i.e. determining specific locations for mariculture. Specifying such zones according to the regional plan would facilitate the concession award process and protect businesses from the uncertainty with respect to investments, as well as facilitate environmental monitoring. Marguš et al. (2001) published a review of research in shellfish farming in the Krka River Estuary for a twenty-year period, then Marguš (2009) cited the success of thirty years of shellfish culture in the Krka River Estuary. Andric et al. (2010) described the procedure and the criteria for fish cages allocation and Slišković and Jelić (2002) emphasize the problem of biofouling on nets. In order to prevent biofouling, antifouling coatings should be used, however, coatings have negative effects on cultivated species and the environment. Slišković et al. (2003) suggested that the impact of aquaculture on surrounding waters could be monitored by net fouling in a simple qualitative and quantitative study of fouling community. Depending on the structure and abundance of certain species, fouling can draw attention to environmental changes in waters near the farm. Skejic et al. (2012) concluded that phytoplankton composition might indicate the occurrence of eutrophication and they conducted a research in which they determine phytoplankton composition on a fish farm at Maslinova. Heterotrophic bacteria play a significant role in the process of decomposition of organic matter in the water environment and they indicate eutrophication, therefore Kapetanović et al. (2012) conducted a study in which the number of heterotrophic bacteria was determined on numerous farms of sea bass Dicentrarchus labrax (Linnaeus 1758 ) along the eastern coast of the Adriatic Sea. In order to preserve the marine environment, Župan et al. (2012) discussed possibilities of developing integrated multitrophic aquaculture in the Adriatic Sea.

\section{FISH NUTRITION AND PRODUCT QUALITY}

Fijan (1981) believed that feeding fish pelleted food was a measure for the intensification of production and he specified the basic principles for achieving high yield in ponds. In their research on the nutritional value of earthworms, Lozovina et al. (1986) proved many advantages of feeding trout on worms during production. Teskeredžić et al. (1994) described the materials and chemical composition of feed, energy content and principals on salmon feeding, which are prerequisites for the cultivation of healthy fish. The best food for marine fish fingerlings are rotifers, i.e. Branchionus plicatilits (Skaramuca, 1994). He stated that data about cultivation of rotifers had not been published yet because of a great commercial importance in mariculture. In addition to natural feed, there are other sources of protein but the best are those which have amino acid composition most similar to fish protein or natural fish feed. Therefore, Debeljak and Fašaić (1980) suggested dry yeast as a possible supplement to food. They stated that the amino acid composition of yeast protein corresponded to the nutrient requirements of carp, especially because it contained essential amino acids that carp could not synthesize but was receiving by feed. Aničić et al. (1992) experimented with concentrated feed for common carp fingerlings until its one year old, while Bogut et al. (1994) conducted an experiment of adding Polyzime to the feed for carp fingerlings. Safner et al (2001) investigated the dressing percentage on the four Croatian populations of common carp. Teskeredžić (2005) published a review of nutrient needs in trout $O$. mykiss feeding. Proper nutrition from a balanced diet is very important in mariculture. Therefore, Bavčević et al. (2006) reviewed the impact of feed of different composition to the growth of gilthead sea bream Sparus aurata during the winterspring period and the potential impact on the occurrence of winter disease syndrome. Bavčević and Lovrinov (2006) described the feed in the cage breeding of sea bream and 
sea bass, and they also described the prospects of fish feed production in Croatia. Arapov et al. (2010) studied the biology of the digestive system of shellfish and their feed. Bogut et al. (2010) conducted a study of the nutritive value of planktonic cladoceran Daphnia magna in the nutrition of carp fingerlings. Fishmeal and fish oil are irreplaceable in the nutrition of carnivorous fish species. Matulić et al. (2011) argued that the excessive fish exploitation for producing fish oil and fishmeal would result in depletions of marine populations. Therefore, in their work, they discussed alternative economical sources of proteins produced from plant, animal or combined, and substitutes from unicellular sources and fishmeal substitutes from less important species. Janči et al. (2013) conducted a study of nutritional value of farmed rainbow trout Oncorhynchus mykiss and they proved that fresh and smoked fillets of rainbow trout reared in the Adriatic Sea could be considered as a food of high nutritional value.

\section{IMPROVING AQUACULTURE}

Taler (1952) provided the guidelines on farming salmonids in the former Yugoslavia. Ristic (1973) listed development opportunities of lagoon breeding in the coastal part of the Adriatic. He claimed that it was possible to breed species such as sea bass, grey mullet, eel, sea bream, flounder Platichthys flessus (Linnaeus 1758), smelt Atherina hepsetus (Linnaeus 1758), grass goby Zosterisessor ophiocephalus (Pallas 1814), etc. History and perspectives of Croatian mariculture were indicated by Skaramuca et al. (1997) while Katavić and Vodopija (2001) cited a number of measures to be implemented for improving the same production sector in Croatia. Pažur (2001) described the situation and prospects of freshwater fish farming. He argued that it was necessary to implement radical changes in production and market spheres. Same author emphasized the problems and possible solutions of freshwater aquaculture regarding cormorant damage (Pažur, 1996; 2002). A review of the impact of great cormorant (Phalacrocorax carbo sinensis) on the fish stock was also presented by Piria (2014). Status and prospects of freshwater aquaculture was also described by Safner (2008). Research has been done on the possibilities of starting the production of new species of shellfish such as Noah's Ark (Župan, 2012) and striped venus clam Chamelea gallina (Linnaeus 1758) (Dupčić and Bratoš, 2004).

\section{SPECIES BIOLOGY AND ECOLOGY}

In order to successfully produce living organisms, it is necessary to know their biology and ecology. Morović and Sabioncello (1963) published an article on bioecology of mullet Mugilidae sp. and how it endured the transition from the sea into fresh water. Ržaničanin and Treer (1979) published a review of breeding tench and carp fingerlings in which they described the biological characteristics of breeding tench and carp. Fijan et al. (1989) described the taxonomy of North American catfish Ictalurus nebulosus (Le Sueur 1816), and its production. In order to introduce new species into production - Mediterranean scallop Pecten jacobaeus (Linnaeus 1758), Marguš and Teskeredžić (2005) conducted a study on the life cycle of scallop, i.e. on acceptance of larvae, survival and growth of juvenile phases in a controlled breeding in the Krka River Estuary. Variegated scallop Chlamys varia (Linnaeus 1758) has been considered for production, therefore Antolović and Antolović (2012) provided an overview of biological and ecological characteristics of variegated scallop that would help the development of controlled breeding. Pećarević and Bratoš-Cetinić (2005) described life cycle of sponges, with suggestions for cultivation. Kružić et al. (2016) cited the biological and ecological characteristics of shadefish Argyrosomus regius (Asso, 1801) that enabled its successful production in the Adriatic Sea.

\section{CONCLUSION}

Aquaculture research in Croatia was regularly conducted, which is evident from numerous published scientific articles in Croatian Journal of Fisheries. Published articles are related primarily to freshwater breeding and, as sea farming started to develop, to mariculture. All articles have been published with the aim of solving various issues in aquaculture and to inform the concerned public about occurrences in Croatia's aquaculture. The Croatian Journal of Fisheries has significantly contributed to the development of aquaculture research in Croatia.

\section{Sažetak}

\section{PREGLED ISTRAŽIVANJA AKVAKULTURE HRVATSKE KROZ ČLANKE OBJAVLJENE U ČASOPISU CROATIAN JOURNAL OF FISHERIES OD 1938. GODINE}

U radu je obuhvaćen 151 članak publiciran u časopisu Croatian Journal of Fisheries od 1938. do 2016. godine koji se bavi područjem akvakulture u Hrvatskoj. Objavljeni radovi svrstani su u sedam grupa na temelju glavnih predmeta istraživanja. Teme uključuju: statistiku u akvakulturi Hrvatske; bolesti i zdravstvenu zaštitu, uzgojne tehnologije, upravljanje, ekonomiju i zaštitu okoliša, riblju prehranu i kvalitetu proizvoda, poboljšanje akvakulture i biologiju i ekologiju vrsta. Ovaj rad sažeto informira o istraživanjima u akvakulturi u Hrvatskoj od 1938. godine. Zbog velikog doprinosa istraživanju, razvoju i kvaliteti upravljanja hrvatskom akvakulturom potrebno je $\mathrm{i}$ dalje promicati $\mathrm{i}$ razvijati časopis Croatian Journal of Fisheries. 
Ključne riječi: statistika, bolesti, upravljanje, ekonomija, prehrana, kvaliteta proizvoda

\section{REFERENCES}

Andrić, V., Jelić Mrčelić, G., Slišković, M., Miletić, (2010): The procedure and the criteria for fish cages allocation. Croatian Journal of Fisheries, 68 (4) 167 - 174

Aničić, I., Safner, R., Treer, T., Vranešić, N., Ržaničanin, B., Kovačina, D. (1992): Concentrated food nutrition of common carp (Cyprinus carpio L.) until it is one-year-old. Croatian Journal of Fisheries, 47 (1-2) 55 - 61

Antolović, M., Antolović, N. (2012): Biološke i ekološke karakteristike male kapice (Chlamys varia, Linnaeus. 1758) osnova kontroliranog uzgoja. Croatian Journal of Fisheries, 70 (1), 31-40

Antonović , I., Treer, T. (2015): A review of freshwater ichthyofauna research published in the Croatian Journal of Fisheries since 1938. Croatian Journal of Fisheries. 73 (4) $176-182$

Arapov, J., Ezgeta - Balić, D., Peharda, M., Ninčević Gladan, Ž. (2010): Prehrana školjkaša - kako i što jedu. Croatian Journal of Fisheries, 68 (3), 105-116.

Basioli, J. (1955): Slatkovodno ribarstvo NR Hrvatske u 1954. godini. Croatian Journal of Fisheries, 10 (1), 18-19.

Basioli, J. (1961): Slatkovodno ribarstvo NR Hrvatske u 1960. godini. Croatian Journal of Fisheries, 16 (3), 67-73.

Basioli, J. (1962): Slatkovodno ribarstvo NR Hrvatske u 1961. godini. Croatian Journal of Fisheries, 17 (2), 46-51.

Basioli, J. (1963): Slatkovodno ribarstvo SR Hrvatske u 1962. godini. Croatian Journal of Fisheries, 18 (3), 82-84

Basioli, J. (1964): Slatkovodno ribarstvo SR Hrvatske u 1963. godini. Croatian Journal of Fisheries, 19 (3), 70-71

Basioli, J. (1965): Slatkovodno ribarstvo SR Hrvatske u 1964. godini. Croatian Journal of Fisheries, 20 (3), 59-63

Basioli, J. ( 1966): Slatkovodno ribarstvo SR Hrvatske u 1965. godini. Croatian Journal of Fisheries, 21 (3), 60-64

Basioli, J. (1967): Slatkovodno ribarstvo SR Hrvatske u 1966. godini. Croatian Journal of Fisheries, 22 (3), 78-82

Basioli, J. (1968): Slatkovodno ribarstvo SR Hrvatske u 1967. godini. Croatian Journal of Fisheries, 23 (4), 86-91

Basioli, J. (1969): Slatkovodno ribarstvo SR Hrvatske u 1968. godini. Croatian Journal of Fisheries, 24 (3), 60-65

Basioli, J. (1970): Slatkovodno ribarstvo SR Hrvatske u 1969. godini. Croatian Journal of Fisheries, 25 (4), 92-97

Basioli, J. (1971): Slatkovodno ribarstvo SR Hrvatske u 1970. godini. Croatian Journal of Fisheries, 26 (3), 58-63

Basioli, J. (1972): Slatkovodno ribarstvo SR Hrvatske u 1971. godini. Croatian Journal of Fisheries, 27 (3), 59-66

Basioli, J. (1973): Slatkovodno ribarstvo SR Hrvatske u 1972. godini. Croatian Journal of Fisheries, 28 (3), 61-68

Basioli, J. (1974): Slatkovodno ribarstvo SR Hrvatske u 1973. godini. Croatian Journal of Fisheries, 29 (3), 54-62

Basioli, J. (1975): Slatkovodno ribarstvo SR Hrvatske u 1974. godini. Croatian Journal of Fisheries, 30 (3), 65-75

Basioli, J. (1976): Slatkovodno ribarstvo SR Hrvatske u 1975. godini. Croatian Journal of Fisheries, 31 (3), 51-56

Basioli, J. (1977): Slatkovodno ribarstvo SR Hrvatske u 1976. godini. Croatian Journal of Fisheries, 32 (3), 62-67

Basioli, J. (1978): Slatkovodno ribarstvo SR Hrvatske u 1977. godini. Croatian Journal of Fisheries, 33 (3), 70-75

Basioli, J. (1979): Slatkovodno ribarstvo SR Hrvatske u 1978. godini. Croatian Journal of Fisheries, 34 (3), 65-70

Bauer, J. (1970): Mehanizacija u ribnjačarstvu i organizacija proizvodnih procesa. Croatian Journal of Fisheries, 25 (2), 45-47

Bauer, J. (1974): Pokušaj uvođenja gravitacionog sistema za mriještenje i uzgoj mlađa na šaranskim ribnjacima. Croatian Journal of Fisheries, 29 (2), 26-32

Bavčević, L., Lovrinov, M. (2006): Hrana za kavezni uzgoj lubina i komarče - razvoj i perspektive. Croatian Journal of Fisheries, 64 (3), 103-112

Bavčević, L., Petrović, S., Crnica, M., Corazzin, E. (2006): Učinak hranjenja i vrste hrane na rast podlanice (Sparus aurata L.) tijekom zimsko - proljetnog razdoblja i mogući utjecaj na pojavu sindroma zimske bolesti. Croatian Journal of Fisheries, 64 (1), 1-17

Bavčević, L., Vodopija, T., Lovrinov, M. (2001): Zoniranje obalnog pojasa za marikulturu - stanje. Croatian Journal of Fisheries, 59 (4), 150-158

Bogut, I., Adamek, Z., Puškadija, Z., Galović, D. (2010): Nutritional value of planktonic cladoceran daphnia magna for common carp (Cyprinus carpio) fry feeding. Croatian Journal of Fisheries, 68 (1), 1-10

Bogut, I., Opačak, A., Stević, I., Bogdanić, Č. (1994): Utjecaj dodatka polyzima u hrani na rast šaranskog mlađa (Cyprinus carpio). Croatian Journal of Fisheries, 52 (49) (2), 65-75

Čadež, V. (2005): Bolesti školjkaša regulirane zakonom u Republici Hrvatskoj. Croatian Journal of Fisheries, 63 (3), 105-116

Čehović, Đ. (1952): Izazivanje i ubrzavanje mrijesta kod riba pomoću hipofizarnih injekcija. Croatian Journal of Fisheries, 7 (11-12), 182-184

Čičin - Karlov, D. I Teskeredžić, Z. (2005): Ektoparazitoze uzgajanih riba. Croatian Journal of Fisheries, 63 (1), 1520

Debeljak, Lj., Fašaić, K. (1980): Suhi kvasac u ishrani mladunaca šarana. Croatian Journal of Fisheries, 35 (5), 97-101

Debeljak, Lj., Turk, M. (1981): Gustoća nasada kao faktor povećanja proizvodnje ribe u šaranskim ribnjacima. Croatian Journal of Fisheries, 36 (2), 25-29

Dupčić, I., Bratoš, A. (2004): Mogućnost uzgoja kućice Chamelea gallina (Linnaeus, 1758) uz istočnu obalu Jadrana. Croatian Journal of Fisheries, 62 (3), 103-108

Fijan, N. (1947): Ascites - vodena trbušna bolest šarana. Croatian Journal of Fisheries, 2 (6-7), 69

Fijan, N. (1948): Nasađivanje smuđeva prenašanjem 
oplođene ikre. Croatian Journal of Fisheries, 3 (11-12), 115-116

Fijan, N. (1952): Problematika uzgoja šaranskog mlađa. Croatian Journal of Fisheries, 7 (9-10), 156-159

Fijan, N. (1963): Daktilogiroza šarana. Croatian Journal of Fisheries, 18 (3), 70-73

Fijan, N. (1966): Pastrvski okun - sporedna riba grabilica za bolje iskorištavanje ribnjka. Croatian Journal of Fisheries, 21 (4), 80

Fijan, N. (1970): O zaraznoj nekrozi gušterače pastrvskih riba. Croatian Journal of Fisheries, 25 (3), 60-62

Fijan, N. (1971): Mjere za suzbijanje bolesti na ribogojilištima. Croatian Journal of Fisheries, 26 (2), 29-31

Fijan, N. (1978a): Današnje stanje poznavanja eritrodermatitisa šarana. Croatian Journal of Fisheries, 33 (2), 27-30

Fijan, N. (1978b): Najvažnije bolesti biljojednih riba. Croatian Journal of Fisheries, 33 (4), 96-101

Fijan, N. (1981): Hranidba ribe peletiranom hranom kao mjera za intenziviranje proizvodnje. Croatian Journal of Fisheries, 36 (1), 1-4

Fijan, N. (1989): Zdravlje riba. Croatian Journal of Fisheries, 44 (2), 39-40

Fijan, N., Kunšt, Lj., Malnar, J. (1962): Liječenje šarana od šaranske uši kod niske temperature kupanjem u lindanu. Croatian Journal of Fisheries, 17 (3), 65-67

Fijan, N., Petrinec, Z., Đorđević, V. (1989): Taksonomija i proizvodnja sjevernoameričkih somova roda Ictalurus. Croatian Journal of Fisheries, 44 (5), 109-113

Fijan, N., Vojta, J. (1969): Prvo mriještenje bijelog tolstolobika i bijelog amura na Ribnjačarstvu Končanica. Croatian Journal of Fisheries, 24 (6), 124-125

Habeković, D. (1978): Prvi rezultati kaveznog uzgoja kalifornijske pastrve u jezerskim uvjetima. Croatian Journal of Fisheries, 33 (3), 52-64

Habeković, D. (1982): Uzgoj kalifornijske pastrve u kavezima. Croatian Journal of Fisheries, 37 (1), 4-8

Habeković, D., Mišetić, S., Marko, S. (1981): Kavezni uzgoj Coregonus peleda. Croatian Journal of Fisheries, 36 (6), 121-127

Habeković, D., Turk, M. (1981): Neki podaci selekcije šarana u SRH. Croatian Journal of Fisheries, 36 (5), 99-101

Hacmanjak, M. (1985). Telohaneloza - sve učestalija bolest u našim ribnjacima. Croatian Journal of Fisheries, 40 (45-6): 94-96

Homen, Z., Jahutka, I. (2000). Stanje u uzgoju slatkovodne ribe u godini 1999. te plan proizvodnje za godinu 2000. Croatian Journal of Fisheries, 58 (3), 119-132

Jahutka, I., Homen, Z. (2001): Hrvatsko slatkovodno ribarstvo u 2000. godini s prijedlogom mjera za rješavanje problema u proizvodnji. Croatian Journal of Fisheries, 59 (3), 107-120

Jahutka, I., Homen, Z. (2003): Hrvatsko slatkovodno ribarstvo u 2001. i 2002. godini. Croatian Journal of Fisheries, 61 (3), 121-134
Jahutka, I., Mišura, A., Homen, Z. (2004): Ribarstvo Republike Hrvatske u godini 2003. Croatian Journal of Fisheries, 62 (4), 143-164

Jahutka, I., Mišura, A., Suić, J., Franičević, V., Homen, Z., Marković, J. (2005): Hrvatsko ribarstvo u 2004. godini. Croatian Journal of Fisheries, 63 (4), 147-142

Jahutka, I., Mišura, A., Suič, J., Franičević, V., Homen, Z., Marković, J. (2007): Hrvatsko ribarstvo u 2006. godini. Croatian Journal of Fisheries, 65 (4), 141-160

Jahutka, I., Mišura, I., Suić, J. (2006): Hrvatsko ribarstvo u godini 2005. Croatian Journal of Fisheries, 64 (4), 149170

Janči, T., Kanski, D., Dulić, M., Marušić, N., Medić, H., Petrak, T., Vidaček, S. (2013): Prehrambena vrijednost kalifornijske pastrve (Oncorhynchus mykiss) uzgojene u Jadranskom moru. Croatian Journal of Fisheries, 71 (2), 58-64

Jelkić, D., Opačak, A., Stević, I., Ozimec, S., Jug-Dujaković, J., Safner, R. (2012): Rearing carp larvae (Cyprinus carpio) in closed recirculatory system (RAS). Croatian Journal of Fisheries, 70 (1), 9-17

Kapetanović, D., Dragun, Z., Valić, D., Vardić Smrzlić, I., Teskeredžić, Z., Teskeredžić, E. (2012): Određivanje broja heterotrofnih bakterija u Jadranskim uzgajalištima primjenom različitih metoda. Croatian Journal of Fisheries, 70 (Supplement 1), S29-S37

Kapetanović, D., Teskeredžić, E. (2004): Aeromonasna bakterijemija mlađi kalifornijske pastrve (Oncorhynchus mykiss), osjetljivost prema antimikrobnim tvarima. Croatian Journal of Fisheries, 62 (3), 95-102

Katavić, I., Vodopija, T. (2001): Razvojne mogućnosti marikulture u Republici Hrvatskoj, Croatian Journal of Fisheries, 59 (2), 71-84

Križanac, V., Teskeredžić, E. (1980): Pojava bakterijskog nefritisa u kalifornijskih pastrva (Salmo gairdneri Rich.) nakon masovnog uginuća uslijed neadekvatne hrane i načini liječenja. Croatian Journal of Fisheries, 35 (2), 27-33

Kezić, N, Fijan, N. (1974): O zaraznoj upali plivaćeg mjehura. Croatian Journal of Fisheries, 29 (1), 4-8

Kružić, N., Mustać, B., Župan, I., Čolak, S. (2016): Meagre (Argyrosomus regius Asso, 1801) aquaculture in Croatia. Croatian Journal of Fisheries, 74 (1), 14-19

Kuhinek, M. (1979): „Ribnjačarstvo Končanica“ uvodi u proizvodnju nove vrste riba. Croatian Journal of Fisheries, 34 (5), 117-118

Kunst, Lj. (1965): Primjena kupki u liječenju ektoparazitarnih invazija kod šarana. Croatian Journal of Fisheries, 20 (6), 122-126

Kurtović, B., Teskeredžić, T. (2001): Zoonoze organizama koji žive u vodi. Croatian Journal of Fisheries, 59 (4), 159-169

Labar, Đ., Toth, I. (1983): Mrežasti kavezi za intenzivan uzgoj riba. Croatian Journal of Fisheries, 38 (3), 69-71

Livojević, Z. (1970): Mogućnost povišenja prinosa šarana i prateće ribe na $2.000 \mathrm{~kg} / \mathrm{ha}$. Croatian Journal of Fisheries, 25 (2), 42-45 
Livojević, Z., Habeković, D. (1966): Suzbijanje zvbš-a pomoću antibiotika u hrani. Croatian Journal of Fisheries, 21 (3), 45-49

Lozovina, M., Domenico Stefanuto, P. (1986): Uzgoj domestificiranih glista na ribnjacima i njihova primjena $u$ prehrani riba. Croatian Journal of Fisheries, 41 (1-2), 27-30

Marguš, D. (2009): Tri desetljeća uzgoja školjkaša u ušću rijeke Krke. Croatian Journal of Fisheries, 67 (2), 77-85

Marguš, D., Teskeredžić, E. (2005): Prihvat ličinki, preživljenje i rast juvenilnih jakovskih kapica (Pecten jacobaeus Linnaeus, 1758.) u kontroliranom uzgoju u uvali Šarina draga - ušće rijeke Krke. Croatian Journal of Fisheries, 63 (1), $1-14$

Marguš, D., Teskeredžić, E., Šain, Ž. (2001): Dvadeset godina istraživanja i uzgoja školjkaša u ušću rijeke Krke. Croatian Journal of Fisheries, 59 (3), 121-130

Marko, S., Stoisavljević, J. (1972): Rezultati mriještenja bijelog amura na Ribnjačarstvu Grudnjak. Croatian Journal of Fisheries, 27 (6), 139-140

Matulić, D., Aničić, I., Grbeša, D., Boban, M. (2011): Zamjena ribljeg brašna, kao dominantnog izvora proteina $u$ akvakulturi, alternativnim hranidbenim komponentama. Croatian Journal of Fisheries, 69 (3), 101-126

Matulić, D., Ivanković, A., Aničić, I. (2009): Potpomognuta selekcija u akvakulturi. Croatian Journal of Fisheries, 67 (1), 25-39

Milinković, R. (1988): Proizvodnja i potrošnja pastrmke u Jugoslaviji u 1987. godini. Croatian Journal of Fisheries, 43 (5-6), 111-113

Mišura, A., Jahutka, I., Skakelja, N., Suić, J., Franičević, V. (2008): Hrvatsko ribarstvo u 2007. godini. Croatian Journal of Fisheries, 66 (4), 157-175,

Morović, D., Sabioncello, I. (1963): Prinosi istraživanju bioekologije cipala (Mugilida). Croatian Journal of Fisheries, 18 (6), 159-163

Pažur, K. (1996): Cormorant - a problem and a possible solution. Croatian Journal of Fisheries, 54 (4) 173 - 180

Pažur, K. (2001): Slatkovodno ribarstvo Hrvatske - stanje i perspektive. Croatian Journal of Fisheries, 59 (1), 3-7

Pažur, K. (2002): Cormorant (Phalacrocorax carbo sinensis) and damages on fish stock caused by cormorant hyper population. Croatian Journal of Fisheries, 60, (4), 141147

Pećarević, M., Bratoš-Cetinić, A. (2005): O uzgoju spužava. Croatian Journal of Fisheries, 63 (2), 69-78

Peharda, M., Onofri, V. (2000): Pregled eksperimentalnog postavljanja polietilenskih vreća - kolektora za prikupljanje školjkaša. Croatian Journal of Fisheries, 58 (2), 63-67

Petrinec, Z., Naglić, T., Matašin, Ž., Fijan, N. (1983): Masovna ugibanja sivog glavaša na dva ribnjačarstva uzrokovana bakterijom Pseudomonas fluorescens. Croatian Journal of Fisheries, 38 (3), 58

Piria, M. (2014). A review of the impact of great cormorant (Phalacrocorax carbo sinensis) on the fish stock. Croatian
Journal of Fisheries, 72, (4), $164-173$

Plančić, J. (1938): Slatkovodno ribarstvo Savske banovine. Croatian Journal of Fisheries, 1 (3,4,5,6), 66-74

Popović, J., Habeković, D. (1978): Značenje linjaka (Tinca tinca L. 1758.) u akvakulturi. Croatian Journal of Fisheries, 33 (2), 37-39

Ristić, M. Đ. (1973): Stanje i realne mogućnosti razvoja lagunarnog ribarstva u priobalnom regionu Jadrana. Croatian Journal of Fisheries, 28 (1), 7-8

Ržaničanin, B., Safner, R., Treer, T. (1984a): Rezultati prvog kaveznog uzgoja šarana (Cyprinus carpio L.) u Vranskom jezeru kod Biograda n/m. Croatian Journal of Fisheries, 39 (2), 29-31

Ržaničanin, B., Treer, T. (1979): O uzgoju linjaka i šaranskih mladunaca. Croatian Journal of Fisheries, 34 (6), 122-141

Ržaničanin, B., Treer, T., Safner, R. (1984b): Rezultati prvog kaveznog uzgoja soma (Silurus glanis L.) u Vranskom jezeru kod Biograda n/m. Croatian Journal of Fisheries, 39 (2), 32-35

Ržaničanin, B., Treer, T., Safner, R., Aničić, I. (1986): Unapređivanje kaveznog uzgoja soma (Silurus glanis L.) na Vranskom jezeru kod Biograda n/m. Croatian Journal of Fisheries, 41 (4-5), 69-71

Sabioncello, I. (1963): Uspješan prijevoz cipalske mlađi. Croatian Journal of Fisheries, 18 (3), 84

Sabioncello, I., Turk, M., Runac, M. (1970): Uzgoj soma kao dopunske ribe u šaranskim ribnjacima. Croatian Journal of Fisheries, 25 (3), 63-64

Safner, R.(2008): Uzgoj slatkovodne ribe, stanje i perspektive. Croatian Journal of Fisheries, 66 (2), 82-84

Safner, R., Treer, T., Aničić, I., Kolak, A. (2001): Dressing percentage of four Croatian common carp (Cyprinus Carpio L.) populations. Croatian Journal of Fisheries, 59 (4) 131 $-141$

Šarić, I., Brailo, M., Gavrilović, A., Jug-Dujaković, J. (2010): Biofilters in aquaculture. Croatian Journal of Fisheries 68 (3), $117-132$

Skaramuca, B. (1994): Značaj rotatorija (Branchionus plicatilis, Müller) za akvakulturu. Croatian Journal of Fisheries, 52 (49) (2), 75-89

Skaramuca, B., Teskeredžić, E., Teskeredžić, Z. (1997): Mariculture in Croatia, history and perspectives. Croatian Journal of Fisheries, 55 (1) 19 - 26

Skejič, S., Marasović, I., Ninčević Gladan, Ž. (2012): Phytoplankton assemblages at fish farm in Maslinova bay (the island of Brač). Croatian Journal of Fisheries, 70 (2), 41 52

Slišković, M., Jelić, G. (2002): Problem obraštaja mreža u akvakulturi. Croatian Journal of Fisheries, 60 (3), 105-115

Slišković, M., Jelić, G., Hell, Z. (2003): Obraštaj kaveza za uzgoj ribe kao pokazatelj utjecaja akvakulture na okoliš. Croatian Journal of Fisheries, 61 (1), 27-32

Taler, Z. (1948a): O proučavanju trbušne vodene bolesti šarana. Croatian Journal of Fisheries, 3 (6), 50-54 
Taler, Z. (1948b): Slučaj plinskih mjehurića na pastrvama. Croatian Journal of Fisheries, 3 (5), 38-41

Taler, Z. (1952): Iskustva sa uzgojem salmonida u Jugoslaviji i smjernice za poribljavanje otvorenih voda, te uzgoj konzumne ribe. Croatian Journal of Fisheries, 7 (1-2), 12-15

Teskeredžić, E. (1985): Uzgoj riba u plutajućim kavezima. Croatian Journal of Fisheries, 40 (2-3), 42-48

Teskeredžić, Z. (2005): Prehrana pastrva. Croatian Journal of Fisheries, 63 (2), 47-60,

Teskeredžić, Z., Higgs, D., Dosanjh, B., Teskeredžić, E. (1994): Hrana i načini hranjenja salmonida kao preduvjet za uzgoj zdrave ribe. Croatian Journal of Fisheries, 59 (49) (1), 33-46

Tomašec, I. (1953): Crijevne invazije helmintima u riba. Croatian Journal of Fisheries, 8 (3), 53-55

Tomašec, I., Kunst, Lj. (1965): Bolesti i ugibanja šarana u toku zimovanja. Croatian Journal of Fisheries, 20 (1), 1014

Tomec, M., Hacmanjek, M., Teskeredžić, Z., Teskeredžić, E., Čož - Rakovec, R. (1995): Kvaliteta vode i ektoparazitarne bolesti ciprinidnih riba. Croatian Journal of Fisheries, 53 (4), 129-139

Topić Popović, N., Teskeredžić, E. (1999): Bolesti i toksini školjka regulirani zakonom. Croatian Journal of Fisheries, 57 (2), 65-83

Turk, M. (1978): Utjecaj biljojednih riba na ekonomičnost proizvodnje u šaranskim ribnjacima. Croatian Journal of Fisheries, 33 (4), 88-92

Turk, M. (1980): Slatkovodno ribarstvo SR Hrvatske u 1979. godini. Croatian Journal of Fisheries, 35 (4), 84-88

Turk, M. (1981): Slatkovodno ribarstvo SR Hrvatske u 1980. godini. Croatian Journal of Fisheries, 36 (4), 85-89

Turk, M. (1982): Slatkovodno ribarstvo SR Hrvatske u 1981. godini. Croatian Journal of Fisheries, 37 (3), 57-63

Turk, M. (1983): Slatkovodno ribarstvo SR Hrvatske u 1982. godini. Croatian Journal of Fisheries, 38 (4), 91-95

Turk, M. (1984): Dvadesetogodišnje razdoblje uzgoja biljojednih riba u ribnjacima Jugoslavije. Croatian Journal of Fisheries, 39 (3-4), 59-64

Turk, M. (1984): Slatkovodno ribarstvo SR Hrvatske u 1983. godini. Croatian Journal of Fisheries, 39 (3-4), 78-82

Turk, M. (1985): Slatkovodno ribarstvo SR Hrvatske u 1984. godini. Croatian Journal of Fisheries, 39 (4-5-6), 97-102

Turk, M. (1986): Slatkovodno ribarstvo SR Hrvatske u 1985. godini. Croatian Journal of Fisheries, 41 (4-5), 89-95

Turk, M. (1987): Slatkovodno ribarstvo SR Hrvatske u 1986. godini. Croatian Journal of Fisheries, 42 (4-5), 107-112

Turk, M. (1988): Slatkovodno ribarstvo SR Hrvatske u 1987. godini. Croatian Journal of Fisheries, 43 (4), 82-88

Turk, M. (1989): Slatkovodno ribarstvo SR Hrvatske u 1988. godini. Croatian Journal of Fisheries, 44 (3-4), 54-60

Turk, M. (1990): Slatkovodno ribarstvo Hrvatske u godini 1989. Croatian Journal of Fisheries, 45 (4), 73-79

Turk, M. (1991): Hrvatsko slatkovodno ribarstvo u godini 1990. Croatian Journal of Fisheries, 46 (3-6), 68-74

Turk, M. (1992): Hrvatsko slatkovodno ribarstvo u godini 1991. Croatian Journal of Fisheries, 47 (3-4), 101-115

Turk, M. (1993): Hrvatsko slatkovodno ribarstvo u godini 1992. Croatian Journal of Fisheries, 48 (3), 97-110

Turk, M. (1994): Hrvatsko slatkovodno ribarstvo u godini 1993. Croatian Journal of Fisheries, 52 (49) (3), 119-133

Turk, M. (1995): Hrvatsko slatkovodno ribarstvo u godini 1994. Croatian Journal of Fisheries, 53 (3), 105-118

Turk, M. (1996): Hrvatsko slatkovodno ribarstvo u godini 1995. Croatian Journal of Fisheries, 54 (3), 115-129

Turk, M. (1997): Hrvatsko slatkovodno ribarstvo u godini 1996. Croatian Journal of Fisheries, 55 (3), 121-133

Turk, M. (1998): Hrvatsko slatkovodno ribarstvo u godini 1997. Croatian Journal of Fisheries, 56 (3), 101-113

Turk, M. (1999): Hrvatsko slatkovodno ribarstvo u godini 1998. Croatian Journal of Fisheries, 57 (3), 135-144

Turk, M., Debeljak, Lj., Fašaić, K. (1987): Rezultati uzgoja biljojednih riba u ribnjačarstvima Hrvatske u razdoblju 1977 - 1986. Croatian Journal of Fisheries, 42 (6), 125-129

Turk, M., Habeković, D. (1981): Hibridizacija bijelog i sivog tolstolobika. Croatian Journal of Fisheries, 36 (5), 97-99

Vegh, M. (1948): Neka opažanja trbušne vodene zaraze kod šarana. Croatian Journal of Fisheries, 3 (7-8), 66

Wunder, W. (1954): O truleži škrga kod šarana na jugoslavenskim ribnjačarstvima i mjere za suzbijanje te bolesti. Croatian Journal of Fisheries, 9 (3), 49-50

Župan, I. (2012): Kunjka (Arca noae, Linnaeus, 1758.) - što moramo znati prije uvođenja ove vrste u akvakulturu? Croatian Journal of Fisheries, 70 (2), 71-81

Župan, I., Peharda, M., Bavčević, L., Šarić, T., Kanski, D., (2012): Mogućnosti razvoja integrirane multi - trofičke akvakulture na Jadranu. Croatian Journal of Fisheries, 70 (1), 125-137

Župan, I., Rogošić, J., Šarić, T., Kanski, D. (2013): Transfer of Arca noae (Linnaeus, 1758) from natural to different experimental farming conditions. Croatian Journal of Fisheries, 71 (4), 187-191 